\title{
The association of wildfire smoke with respiratory and cardiovascular emergency department visits in Colorado in 2012: a case crossover study
}

Breanna L. Alman ${ }^{1 *}$, Gabriele Pfister ${ }^{2}$, Hua Hao ${ }^{3}$, Jennifer Stowell ${ }^{3}$, Xuefei Hư ${ }^{3}$, Yang Liu ${ }^{3}$ and Matthew J. Strickland ${ }^{4}$

\begin{abstract}
Background: In 2012, Colorado experienced one of its worst wildfire seasons of the past decade. The goal of this study was to investigate the relationship of local $\mathrm{PM}_{2.5}$ levels, modeled using the Weather Research and Forecasting Model with Chemistry, with emergency department visits and acute hospitalizations for respiratory and cardiovascular outcomes during the 2012 Colorado wildfires.

Methods: Conditional logistic regression was used to assess the relationship between both continuous and categorical PM 2.5 and emergency department visits during the wildfire period, from June $5^{\text {th }}$ to July $6^{\text {th }} 2012$.

Results: For respiratory outcomes, we observed positive relationships between lag $0 \mathrm{PM}_{2.5}$ and asthma/wheeze $(1 \mathrm{~h}$ max OR 1.01, $95 \% \mathrm{Cl}(1.00,1.01)$ per $10 \mu \mathrm{g} / \mathrm{m}^{3} ; 24 \mathrm{~h}$ mean OR $1.0495 \% \mathrm{Cl}(1.02,1.06)$ per $\left.5 \mu \mathrm{g} / \mathrm{m}^{3}\right)$, and COPD $(1 \mathrm{~h} \mathrm{max}$ OR 1. $0195 \% \mathrm{Cl}(1.00,1.02)$ per $10 \mu \mathrm{g} / \mathrm{m}^{3} ; 24 \mathrm{~h}$ mean $\mathrm{OR} 1.0595 \% \mathrm{Cl}(1.02,1.08)$ per $\left.5 \mu \mathrm{g} / \mathrm{m}^{3}\right)$. These associations were also positive for 2-day and 3-day moving average lag periods. When $\mathrm{PM}_{2.5}$ was modeled as a categorical variable, bronchitis also showed elevated effect estimates over the referent groups for lag $024 \mathrm{~h}$ average concentration. Cardiovascular results were consistent with no association.
\end{abstract}

Conclusions: We observed positive associations between $\mathrm{PM}_{2.5}$ from wildfire and respiratory diseases, supporting evidence from previous research that wildfire $\mathrm{PM}_{2.5}$ is an important source for adverse respiratory health outcomes.

Keywords: Wildfires, Respiratory, Cardiovascular, Emergency department visits, PM2.5, Particulate matter

\section{Background}

Between March $26^{\text {th }}$ and July $10^{\text {th }} 2012$, Colorado experienced one of its worst wildfire seasons of the past decade [1]. By the time the final fires were contained, over 600 homes had been destroyed [2], and an estimated 32,000 people had been evacuated from areas near actively burning fires [3]. While the physical damage to homes and property is readily apparent, wildfire smoke is also a health hazard.

Concentrations of particulate matter less than $2.5 \mu \mathrm{m}$ in diameter $\left(\mathrm{PM}_{2.5}\right)$ can be substantially elevated during

\footnotetext{
* Correspondence: alman.breanna@epa.gov

${ }^{1}$ The Office of Air Quality Planning and Standards, United States Environmental Protection Agency, 109 T.W Alexander Dr, Research Triangle Park, NC 27711, USA

Full list of author information is available at the end of the article
}

wildfire events compared to non-fire situations [4]. Short-term increases in outdoor $\mathrm{PM}_{2.5}$ concentrations have been designated as "likely to be causal" in regard to respiratory morbidity and "causal" in regard to cardiovascular morbidity by the US Environmental Protection Agency, based on current epidemiologic and toxicological literature [5], and wildfire $\mathrm{PM}_{2.5}$ has been linked with several health problems, most notably adverse respiratory outcomes [6]. Recent toxicological studies have shown that $\mathrm{PM}_{2.5}$ from wildfires may have different health effects than typical urban ambient $\mathrm{PM}_{2.5}$, particularly in the amount of oxidative stress generated, which may be due to differences in chemical composition $[7,8]$.

Although many epidemiologic studies have examined associations between respiratory and cardiovascular hospital admissions and urban air pollution, studies on the 
health effects of wildfire smoke are less common. Associations have been reported between exposure to $\mathrm{PM}_{2.5}$ during wildfires and hospital admissions [9] and emergency department (ED) visits [10-14] for respiratory illnesses. Cardiovascular morbidity has been linked to exposure to ambient PM [5], but among $\mathrm{PM}_{2.5}$ and $\mathrm{PM}_{10}$ from wildfires, results have been less consistent, with some studies showing a positive relationship [9, 10, 14], some showing negative relationships [15] and some showing no relationship [13, 16-18].

The 2012 Colorado wildfires present an interesting situation: they burned continuously throughout the summer months, affected a wide geographic area across the state, thus allowing for a larger sample size than often found during typical wildfire periods, and created highly variable $\mathrm{PM}_{2.5}$ concentrations both spatially and temporally. Given the intensity of the Colorado wildfire season of 2012 and the potential for strong adverse respiratory effects from exposure to particulate matter from wildfires, it is important to assess the health impacts associated with wildfire air pollution. The goal of this study is to estimate associations between local $\mathrm{PM}_{2.5}$ levels and ED visits and acute hospitalizations for six respiratory and seven cardiovascular outcomes during the Colorado wildfires of 2012.

\section{Methods}

Hourly $\mathrm{PM}_{2.5}$ concentrations between June 5th and July 6th 2012 were modeled using the Weather Research and Forecasting Model with Chemistry (WRF-Chem) [19]. This model was run at a $12 \mathrm{~km}$ by $12 \mathrm{~km}$ spatial resolution across the Western US, and its outputs were used to characterize $\mathrm{PM}_{2.5}$ and ozone throughout Colorado. The Model for Ozone and Related chemical Tracers (MOZART-4) [20] was used for the chemical boundary conditions, and the National Center for Environmental Protection's North American Mesoscale Forecast System (NCEP/NAM) was used for the meteorological boundary conditions. The wildfire emission estimates used to inform the model are based on the NCAR Fire Inventory (FINN) [21] with the burned area product from the SMARTFIRE framework (provided by Sean Raffuse, Sonoma Technology). The model simulations have been evaluated with operational meteorological observations, satellite retrievals of carbon monoxide, aerosol optical depth, ozone, and $\mathrm{PM}_{2.5}$ measurements from the EPA surface network. The latter are most relevant when using the model product in a health analysis, though it cannot be expected that the often highly localized characteristics of these sites can be captured by the model's spatial resolution. For these analyses, we calculated the $\mathrm{PM}_{2.5} 24 \mathrm{~h}$ daily mean and $1 \mathrm{~h}$ daily maximum for each of these $12 \mathrm{~km}$ by $12 \mathrm{~km}$ grid cells. Fine particles were identified as the size of interest because of their overall association with cardiovascular and respiratory endpoints [5].
Although $24 \mathrm{~h}$ average $\mathrm{PM}_{2.5}$ concentrations may be the most relevant index for health effects [5], $1 \mathrm{~h}$ max concentrations were also assessed, as a high $1 \mathrm{~h}$ max concentration could trigger a health event. While the fires burned between March $26^{\text {th }}$ and July $10^{\text {th }}$, WRF-Chem simulation was conducted only for the peak burning period from June $5^{\text {th }}$ to July $6^{\text {th }}$.

Temperature data in $12 \mathrm{~km}$ by $12 \mathrm{~km}$ grid cells were interpolated from the North American Land Data Assimilation System (NLDAS) output at $\sim 14 \mathrm{~km}$ resolution [22]. These data are included as a covariate in the epidemiologic analysis, using the mean recorded temperature for the day within the specified area. Grid-level exposure was estimated by spatially joining the meteorological data with the health data.

Staff at the Colorado Department of Public Health and Environment geocoded patient addresses for hospitalizations and ED visits for cardiorespiratory disease during June $5^{\text {th }} 2012$ to July $6^{\text {th }} 2012$ to $12 \mathrm{~km}$ grids. Data elements include information on the age, sex, date of admission, the International Classification of Diseases version 9 (ICD9) code, and payment method of the patient, and are expected to capture all ED visits and hospitalizations in Colorado. Patients living in Colorado with addresses that could not be geocoded were excluded (870 of 10,699 records (8.1\%) could not be geocoded). This study population included patients of all ages.

We examined six respiratory and seven cardiovascular endpoints. Cases were identified using the primary International Classification of Diseases version 9 (ICD 9) diagnosis code. The respiratory endpoints were upper respiratory disease (ICD9:460-465, 466.0), pneumonia (ICD9: 480-486), bronchitis (ICD9: 490), chronic obstructive pulmonary disease (COPD) (ICD9: 491, 492, 496), asthma and wheeze (ICD9: 493-786.07), and respiratory disease (ICD9: 460-465, 466.0, 466.1, 466.11, $466.19,480-486,487,488,490,491,492,496,493-$ 786.07). The cardiovascular endpoints were acute myocardial infarction (MI) (ICD9: 410), ischemic heart disease (IHD) (ICD9: 410-414), dysrhythmia (ICD9: 427), congestive heart failure (ICD9: 428) (CHF), ischemic stroke (ICD9: 433-437), peripheral vascular disease (ICD9: 440, 443, 444, 451-453), and cardiovascular disease (CVD) (ICD9: 410-414, 427, 428, 433-437, 440, 443, 444, 451-453). We analyzed all ED visits and all hospitalizations, with the exception of patient hospitalizations that had an "elective" admit type code and patients who were hospitalized because they came through the emergency room, to avoid double counting. All ED visits and hospitalizations included in the analysis will hereafter be referred to as "ED visits". Due to the lack of individual identifiers, patients that had multiple ED visits were counted multiple times. Human subjects research approved by Emory University IRB \#00066505. 
Conditional logistic regression, where each grid was matched to itself over the 32-day study period, was used to estimate associations between $\mathrm{PM}_{2.5}$ concentrations and the occurrence of ED and acute hospitalizations for each endpoint. This approach compares the number of cases on each day with the number of cases on the other days within the same grid and is analogous to time series study analyzed using conditional logistic regression to control for grid location or a case-crossover analysis with pooling across days in a given stratum [23]. By stratifying on grid cell, this approach controls for timeinvariant confounders that vary spatially but not those confounders that vary temporally.

$\mathrm{PM}_{2.5}$ was modeled as both a continuous and categorical variable to investigate possible departures from linearity. We controlled for grid-level day-of temperature and day of week, and daily 8-h maximum ozone was assessed as a potential confounder in two-pollutant models, but was dropped for parsimony. The analyses spanned from June 5, 2012 to July 6, 2012, thus resulting in 32 observations per stratum. Concordant strata (i.e., those with zero ED visits during the 32-day period) were dropped from the analysis. There were no missing exposure data. All analyses were conducted in SAS 9.3 (Cary, NC). Three different lag periods were examined, lag 0, lag 0-1 moving average, and lag 0-1-2 moving average. We stratified asthma and respiratory disease results by age to examine effect modification.

\section{Results}

$\mathrm{PM}_{2.5}$ model data for the study period are presented in Fig. 1, which shows the location of monitors within the Denver area at six points throughout the wildfire period, as well as a comparison of their measured values to the modelled data. Gridded air quality surfaces were smoothed to better see how variable the plumes were throughout the study period. A more comprehensive comparison of modelled vs monitor data at 21 sites throughout Colorado is available in [Additional file 1: Figure S1], which shows that accuracy to monitor data varied both temporally and spatially. Overall, the model had an absolute bias (i.e., a directionless measure of the average difference between the measured and modelled estimations) of $13 \mu \mathrm{g} / \mathrm{m}^{3}$ for $\mathrm{PM}_{2.5}$ concentrations for

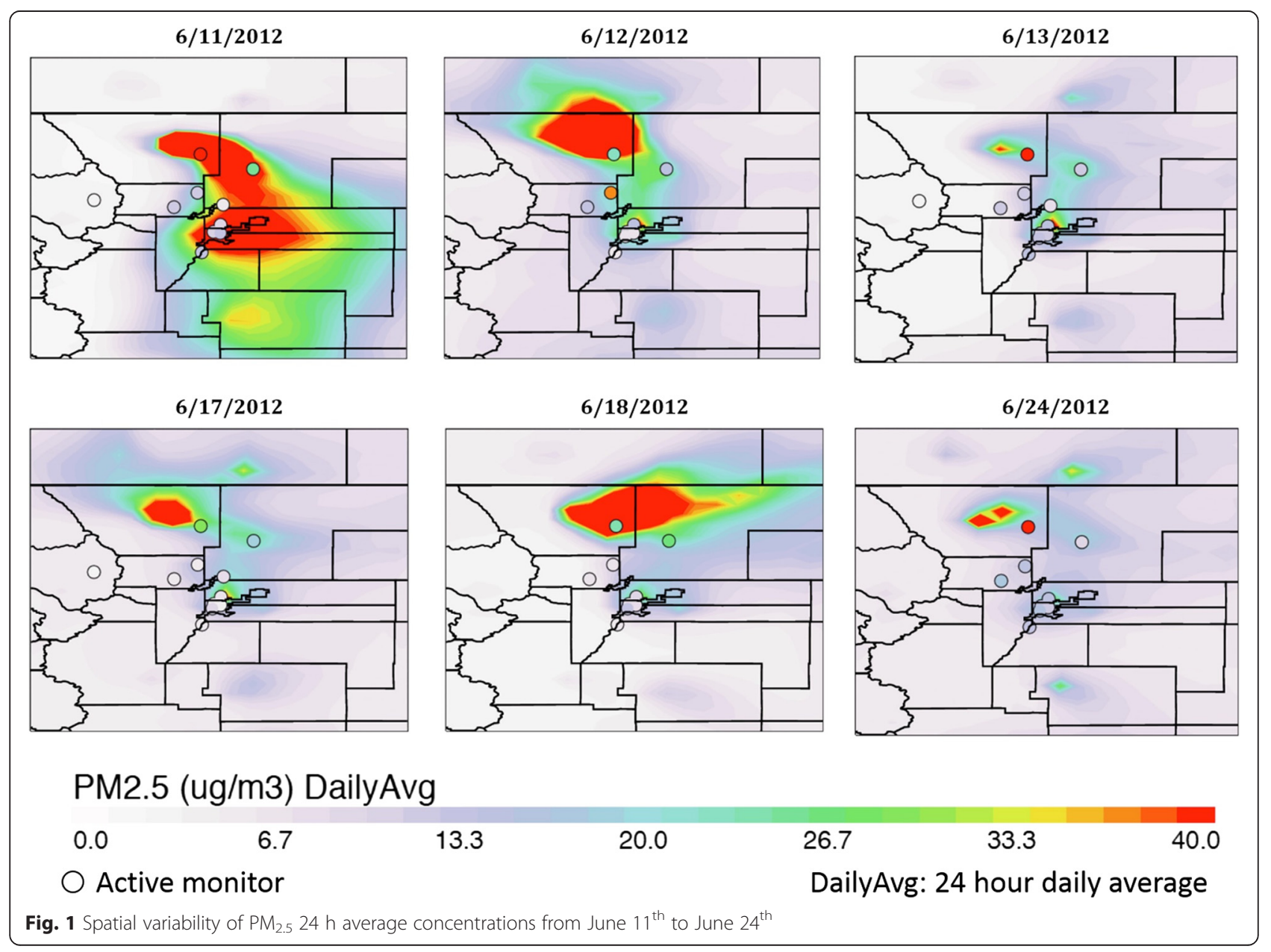


the 6 stations in and around the Denver Metro Area, an area with little fire impact, $13 \mu \mathrm{g} / \mathrm{m}^{3}$ for the 2 stations north-east of Denver, the area most impacted by fires, and $19 \mu \mathrm{g} / \mathrm{m}^{3}$ for the station east of Denver compared to the monitor data. 1-h maximum $\mathrm{PM}_{2.5}$ ranged from $2.02 \mu \mathrm{g} / \mathrm{m}^{3}$ to greater than $5000 \mu \mathrm{g} / \mathrm{m}^{3}$ during the study period. As expected, the more extreme model-simulated $\mathrm{PM}_{2.5}$ levels took place on days of intensive fire activity and at locations near active fire sites. Additionally, $\mathrm{PM}_{2.5}$ levels showed a clear diurnal trend, with an increase in the late afternoon $(\sim 4 \mathrm{pm})$ with peak levels around $7 \mathrm{pm}$ and continuing elevated levels well into the late evening hours. In addition to fire activities, the collapsing planetary boundary layer in the evening would limit the convection of smoke plumes, therefore also contributing to these extreme concentrations during our study period. Moreover, this trend coincides with the diurnal fire emission profiles provided by the Western Regional Air Partnership (WARP) [24].

For respiratory outcomes, when $\mathrm{PM}_{2.5}$ was examined as a continuous variable, we observed positive relationships between $\mathrm{PM}_{2.5}$ and asthma and wheeze $(1 \mathrm{~h} \max$ OR $1.01,95 \%$ CI $(1.00,1.01)$ per $10 \mu \mathrm{g} / \mathrm{m}^{3} ; 24 \mathrm{~h}$ mean OR $1.0495 \%$ CI $(1.02,1.06)$ per $\left.5 \mu \mathrm{g} / \mathrm{m}^{3}\right)$, and COPD
(1 h max OR $1.0195 \%$ CI $(1.00,1.02)$ per $10 \mu \mathrm{g} / \mathrm{m}^{3}$; $24 \mathrm{~h}$ mean OR $1.0595 \% \mathrm{CI}(1.02,1.08)$ per $\left.5 \mu \mathrm{g} / \mathrm{m}^{3}\right)$ (Tables 1 and 2). $\mathrm{PM}_{2.5}$ was also examined as a categorical variable, with each category representing a $10 \mu \mathrm{g} / \mathrm{m}^{3}$ increase in $\mathrm{PM}_{2.5}$ concentration (Figs. 2 and 3). Positive associations between asthma and wheeze and $24 \mathrm{~h}$ mean $\mathrm{PM}_{2.5}$ were also observed when looked at over longer lag periods (Table 1). For case count per concentration category, see [Additional file 2: Table S2].

For the asthma and wheeze outcomes, we observed positive relationships with both $1 \mathrm{~h}$ max and $24 \mathrm{~h}$ average windows with increasing $\mathrm{PM}_{2.5}$ concentrations; this relationship was more pronounced in the $24 \mathrm{~h}$ analysis (Fig. 2). Bronchitis showed elevated effect estimates over the referent groups for $24 \mathrm{~h}$ average; however, the confidence intervals are generally wide, and the relationship with $\mathrm{PM}_{2.5}$ is suggestive of a plateau effect rather than a linear concentration-response relationship, with all effect estimates being similarly elevated over the referent group $\left(<10 \mu \mathrm{g} / \mathrm{m}^{3}\right)$, with the exception of the $>40 \mu \mathrm{g} / \mathrm{m}^{3}$ group. COPD shows a similar pattern for $24 \mathrm{~h}$ average $\mathrm{PM}_{2.5}$, with all concentration groups effect estimates being elevated over the referent group, with the 30-40 $\mathrm{ug} / \mathrm{m}^{3}$ (OR $1.9795 \%$ CI $\left.(1.16,3.34)\right)$ and $>40 \mu \mathrm{g} / \mathrm{m}^{3}$

Table 1 Odds Ratios for respiratory and cardiovascular endpoints for continuous change in 24-h $\mathrm{PM}_{2.5}$ concentrations

\begin{tabular}{|c|c|c|c|c|}
\hline \multirow[t]{2}{*}{ Health endpoint } & \multirow{2}{*}{$\begin{array}{l}\text { Case } \\
\text { count }\end{array}$} & \multicolumn{3}{|c|}{$24 \mathrm{~h}$ mean $\mathrm{OR}^{\mathrm{a}}$ (\% change) } \\
\hline & & $\operatorname{Lag} 0$ & $\operatorname{Lag} 0-1^{\mathrm{b}}$ & Lag $0-1-2^{b}$ \\
\hline \multicolumn{5}{|l|}{ Respiratory } \\
\hline Asthma \& Wheeze (All ages) & 1136 & $1.04(1.02,1.06)$ & $1.05(1.03,1.07)$ & $1.07(1.04,1.10)$ \\
\hline (Ages 0-18) & 387 & $1.02(0.98,1.07)$ & $1.03(0.96,1.10)$ & $1.05(0.97,1.14)$ \\
\hline (Ages 19-64) & 665 & $1.03(1.00,1.06)$ & $1.03(1.00,1.06)$ & $1.07(1.02,1.11)$ \\
\hline (Ages 65+) & 84 & $1.12(0.99,1.27)$ & $1.30(1.06,1.60)$ & $1.29(1.03,1.61)$ \\
\hline Upper respiratory infection & 3376 & $1.02(1.00,1.03)$ & $1.01(0.99,1.04)$ & $1.01(0.98,1.04)$ \\
\hline Pneumonia & 955 & $0.99(0.95,1.03)$ & $1.00(0.95,1.04)$ & $1.00(0.95,1.05)$ \\
\hline Bronchitis & 413 & $1.00(0.94,1.06)$ & $1.01(0.95,1.08)$ & $1.02(0.94,1.10)$ \\
\hline COPD & 628 & $1.05(1.02,1.08)$ & $1.07(1.03,1.11)$ & $1.07(1.02,1.12)$ \\
\hline Respiratory disease (All ages) & 6610 & $1.02(1.01,1.03)$ & $1.03(1.01,1.04)$ & $1.03(1.02,1.05)$ \\
\hline (Ages 0-18) & 2710 & $0.99(0.97,1.02)$ & $0.99(0.96,1.02)$ & $1.01(0.97,1.05)$ \\
\hline (Ages 19-64) & 2915 & $1.03(1.01,1.04)$ & $1.03(1.01,1.05)$ & $1.03(1.01,1.06)$ \\
\hline (Ages 65+) & 985 & $1.02(0.98,1.06)$ & $1.03(0.98,1.09)$ & $1.04(0.98,1.10)$ \\
\hline \multicolumn{5}{|l|}{ Cardiovascular } \\
\hline Acute myocardial infarction & 462 & $1.00(0.96,1.05)$ & $1.01(0.96,1.06)$ & $1.00(0.94,1.06)$ \\
\hline Ischemic heart disease & 722 & $1.01(0.98,1.05)$ & $1.03(1.00,1.08)$ & $1.04(1.00,1.08)$ \\
\hline Dysrhythmia & 1000 & $0.97(0.93,1.02)$ & $0.97(0.92,1.02)$ & $0.92(0.87,0.98)$ \\
\hline Congestive heart failure & 510 & $0.93(0.86,1.00)$ & $0.95(0.88,1.03)$ & $0.94(0.86,1.03)$ \\
\hline Ischemic Stroke & 576 & $0.99(0.95,1.04)$ & $0.96(0.89,1.03)$ & $0.97(0.90,1.05)$ \\
\hline Peripheral vascular disease & 411 & $0.95(0.87,1.03)$ & $0.97(0.89,1.06)$ & $0.93(0.84,1.03)$ \\
\hline Cardiovascular disease & 3219 & $0.98(0.96,1.01)$ & $0.98(0.96,1.01)$ & $0.97(0.94,1.00)$ \\
\hline
\end{tabular}

${ }^{a}$ Change per $5 \mu \mathrm{g} / \mathrm{m}^{3}$

${ }^{b}$ Moving average 
Table 2 Odds Ratios for respiratory and cardiovascular endpoints for continuous change in 24-h PM 2.5 concentrations

\begin{tabular}{|c|c|c|c|c|}
\hline \multirow[t]{2}{*}{ Health endpoint } & \multirow{2}{*}{$\begin{array}{l}\text { Case } \\
\text { count }\end{array}$} & \multicolumn{3}{|l|}{$1 \mathrm{~h} \max \mathrm{OR}^{\mathrm{a}}$} \\
\hline & & $\operatorname{Lag} 0$ & $\operatorname{Lag} 0-1^{b}$ & Lag $0-1-2^{b}$ \\
\hline \multicolumn{5}{|l|}{ Respiratory } \\
\hline Asthma \& Wheeze (All ages) & 1136 & $1.01(1.00,1.01)$ & $1.07(1.04,1.10)$ & $1.02(1.01,1.03)$ \\
\hline (Ages 0-18) & 387 & $1.00(0.99,1.02)$ & $1.01(0.99,1.03)$ & $1.02(0.99,1.05)$ \\
\hline (Ages 19-64) & 665 & $1.01(1.00,1.02)$ & $1.01(1.00,1.01)$ & $1.02(1.00,1.03)$ \\
\hline (Ages 65+) & 84 & $1.06(1.00,1.12)$ & $1.09(1.01,1.18)$ & $1.08(1.00,1.17)$ \\
\hline Upper respiratory infection & 3376 & $1.00(1.00,1.01)$ & $1.03(1.00,1.01)$ & $1.00(0.99,1.01)$ \\
\hline Pneumonia & 955 & $1.00(0.99,1.01)$ & $1.00(0.95,1.05)$ & $0.99(0.98,1.02)$ \\
\hline Bronchitis & 413 & $1.00(0.98,1.02)$ & $1.00(0.98,1.03)$ & $1.01(0.98,1.03)$ \\
\hline COPD & 628 & $1.01(1.00,1.02)$ & $1.02(1.01,1.03)$ & $1.02(1.01,1.04)$ \\
\hline Respiratory disease (All ages) & 6610 & $1.01(1.00,1.01)$ & $1.01(1.00,1.01)$ & $1.01(1.00,1.01)$ \\
\hline (Ages 0-18) & 2710 & $1.00(0.99,1.01)$ & $1.00(0.98,1.01)$ & $1.00(0.99,1.01)$ \\
\hline (Ages 19-64) & 2915 & $1.01(1.00,1.02)$ & $1.01(1.00,1.01)$ & $1.01(1.00,1.02)$ \\
\hline (Ages 65+) & 985 & $1.00(0.99,1.02)$ & $1.01(0.99,1.03)$ & $1.01(0.99,1.03)$ \\
\hline \multicolumn{5}{|l|}{ Cardiovascular } \\
\hline Acute myocardial infarction & 462 & $1.00(0.99,1.02)$ & $1.00(0.98,1.02)$ & $1.01(0.99,1.02)$ \\
\hline Ischemic heart disease & 722 & $1.00(0.99,1.01)$ & $1.03(0.99,1.02)$ & $1.01(0.99,1.02)$ \\
\hline Dysrhythmia & 1000 & $0.98(0.96,1.00)$ & $0.98(0.96,1.00)$ & $0.97(0.94,0.99)$ \\
\hline Congestive heart failure & 510 & $0.98(0.95,1.01)$ & $0.98(0.95,1.01)$ & $0.97(0.94,1.01)$ \\
\hline Ischemic Stroke & 576 & $1.00(0.99,1.01)$ & $0.99(0.97,1.02)$ & $0.99(0.96,1.02)$ \\
\hline Peripheral vascular disease & 411 & $0.98(0.95,1.02)$ & $0.98(0.95,1.02)$ & $0.97(0.93,1.02)$ \\
\hline Cardiovascular disease & 3219 & $0.99(0.98,1.00)$ & $0.99(0.98,1.01)$ & $0.99(0.98,1.00)$ \\
\hline
\end{tabular}

${ }^{a}$ Change per $10 \mu \mathrm{g} / \mathrm{m}^{3}$

b Moving average

(OR $1.9395 \%$ CI $(0.99,3.74)$ ) exposure categories being elevated over the $10-20$ and $20-30 \mu \mathrm{g} / \mathrm{m}^{3}$ exposure groups (OR $1.2795 \%$ CI $(0.90,1.79)$ and OR $1.1595 \%$ CI $(0.76,1.74)$ respectively). However, these elevated associations lacked precision, and were not present in the $1 \mathrm{~h}$ max analyses. We also completed age-stratified analyses for two outcomes, asthma and respiratory disease. Overall, the highest magnitude of effect was seen in those aged 65 and up; however, results were imprecise (Tables 1 and 2).

For cardiovascular outcomes, point estimates were consistently null in the continuous analysis. Cardiovascular outcomes were also largely null in the categorical analysis (Fig. 3). There is some evidence for a negative association between $\mathrm{PM}_{2.5}$ and peripheral vascular disease for the $1 \mathrm{~h}$ daily max at lag 0 , with the $10-20 \mu \mathrm{g} /$ $\mathrm{m}^{3}, 20-30 \mu \mathrm{g} / \mathrm{m}^{3}$, and $>40 \mu \mathrm{g} / \mathrm{m}^{3}$ concentration group ORs falling below the null with similar magnitudes. CHF also had negative effect estimates for the continuous results across all lag periods. Acute myocardial infarction point estimates were all elevated above the null for the $1 \mathrm{~h}$ daily max exposure, with the exception of the highest exposure category $\left(>40 \mu \mathrm{g} / \mathrm{m}^{3}\right)$, though confidence intervals were wide and crossed the null.

\section{Discussion}

The positive associations between $\mathrm{PM}_{2.5}$ from wildfires and respiratory disease observed in this study are consistent with previous published wildfire research. Rappold, et al. [10] found associations between asthma ED visits and wildfire smoke in North Carolina, with the strongest association observed at lag 0 . This study averaged exposure to the county level, giving everyone within the county a uniform distribution of exposure. Rappold, et al. [14] and Moore, et al. [13] and also found positive associations between asthma exacerbation and $\mathrm{PM}_{2.5}$, looking at emergency department and physician visits respectively. We also observed similar positive associations with bronchitis and COPD as Rappold, et al. [14], although they looked specifically at acute bronchitis and pneumonia, whereas our study focused on bronchitis alone and found no association with pneumonia.

We observed differences in effect estimates with age, specifically those above 65 years of age had higher odds of an event, potentially identifying that age group as a susceptible population. Previous studies have also shown that young age can be a significant effect measure modifier with respiratory morbidity $[25,26]$; however, when 


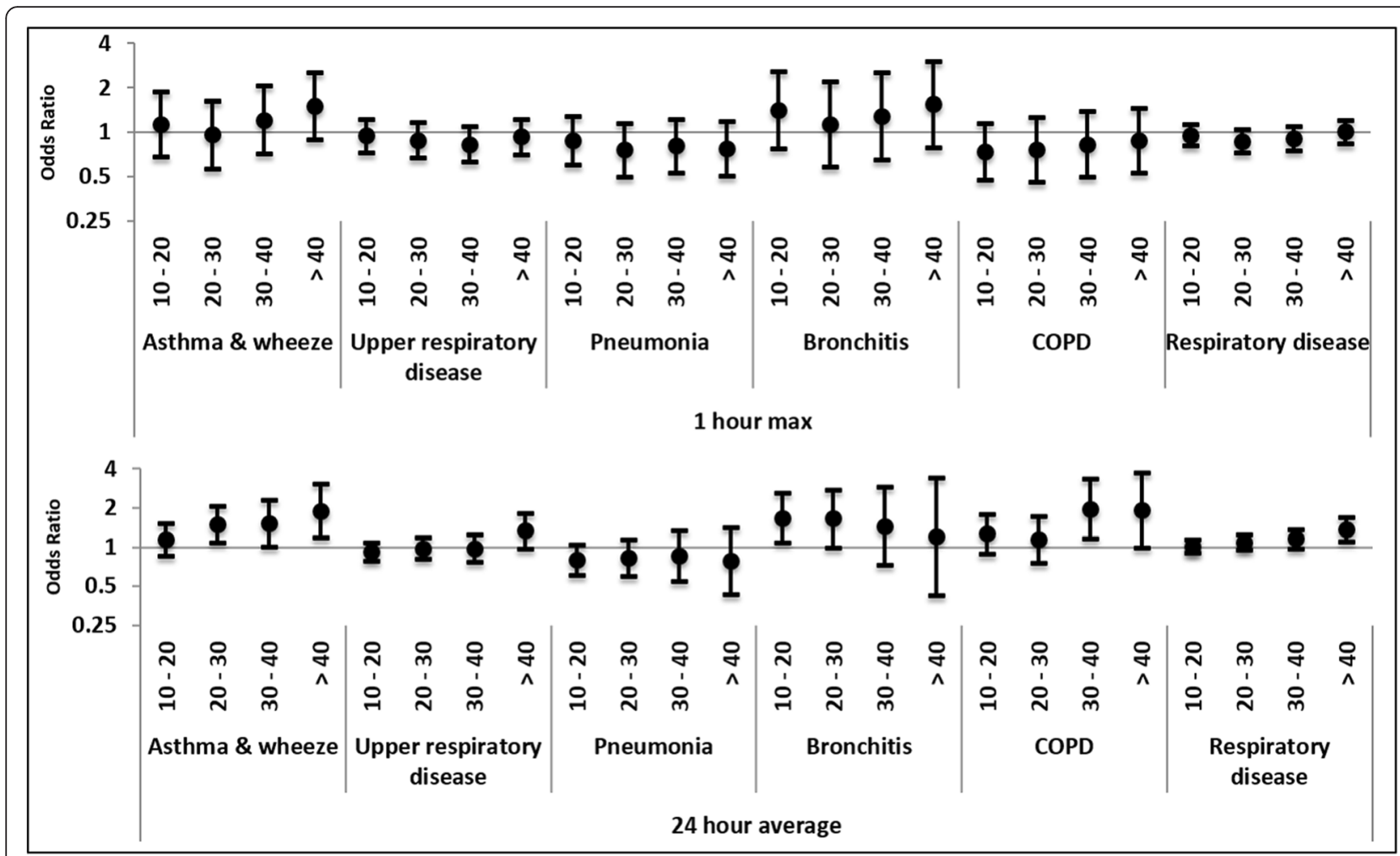

Referent group: $<10 \mu \mathrm{g} / \mathrm{m}^{3}$

Fig. 2 Concentration response odds ratios for respiratory outcomes for $24-\mathrm{h}$ and 1 -h maximum categorical PM 2.5

we stratified by age, effect estimates did not appear to be higher for those ages $0-18$.

Overall, the cardiovascular disease effect estimates in our study were fairly consistent with no association although some confidence intervals were wide. This may be due in part to low case counts for cardiovascular outcomes, and it is important to note that lack of association in our study does not mean that one does not exist. Overall, there are both fewer wildfire studies examining cardiovascular morbidity, and fewer that found a positive relationship between cardiovascular morbidity and wildfire PM than respiratory morbidity, and the majority of studies focused on $\mathrm{PM}_{10}$ rather than $\mathrm{PM}_{2.5}$ [6]. Moore, et al. [13] found similar null cardiovascular results in their study of 2003 fires and $\mathrm{PM}_{2.5}$ in the Kamloops and Kelowna regions of British Columbia. The authors suggest that wildfire smoke may have a selective effect on respiratory outcomes, thus the lack of association. Alternatively, it is plausible that those who know they are at risk for a cardiovascular event may decide to alter their behavior and stay inside or temporarily relocate from an area expected to be impacted by the wildfires; however, one may also expect that behavior to occur in respiratory outcomes. We would expect this exposure misclassification to result in bias downward. We found positive associations with MI, similar to Rappold, et al. [10], though our associations were only found in $1 \mathrm{~h}$ max concentrations, and while the effect estimate was elevated, results were imprecise. However, Rappold, et al. [10] and Delfino, et al. [9], also found evidence for positive associations between exposure to wildfire $\mathrm{PM}_{2.5}$ and $\mathrm{CHF}$ and all cardiovascular outcomes, respectively. A study conducted in the Denver area during a nonwildfire period generally showed similar results to ours in regard to direction of association between respiratory outcomes and $\mathrm{PM}_{2.5}$ concentration. Similar to Kim, et al. [27], we found positive associations between respiratory disease, asthma and $\mathrm{PM}_{2.5}$ exposure, with the magnitude of effect increasing with lag time for asthma. Conversely, they found strong associations between cardiovascular disease and $\mathrm{PM}_{2.5}$, which were strongest at lag 0 , which we did not observe.

Generally, the relationships we observed were weaker when using $1 \mathrm{~h}$ max concentrations. This could be because on days when there was a maximum concentration above $30 \mu \mathrm{g} / \mathrm{m}^{3}$, peak concentrations were observed around $7 \mathrm{pm}$ and remained elevated throughout the evening, and these may be times when people are generally inside, thus potentially limiting their exposure. While we were unable to separate the effects of ambient $\mathrm{PM}_{2.5}$ from $\mathrm{PM}_{2.5}$ stemming from wildfires, it is unlikely that we would normally see ambient concentrations 


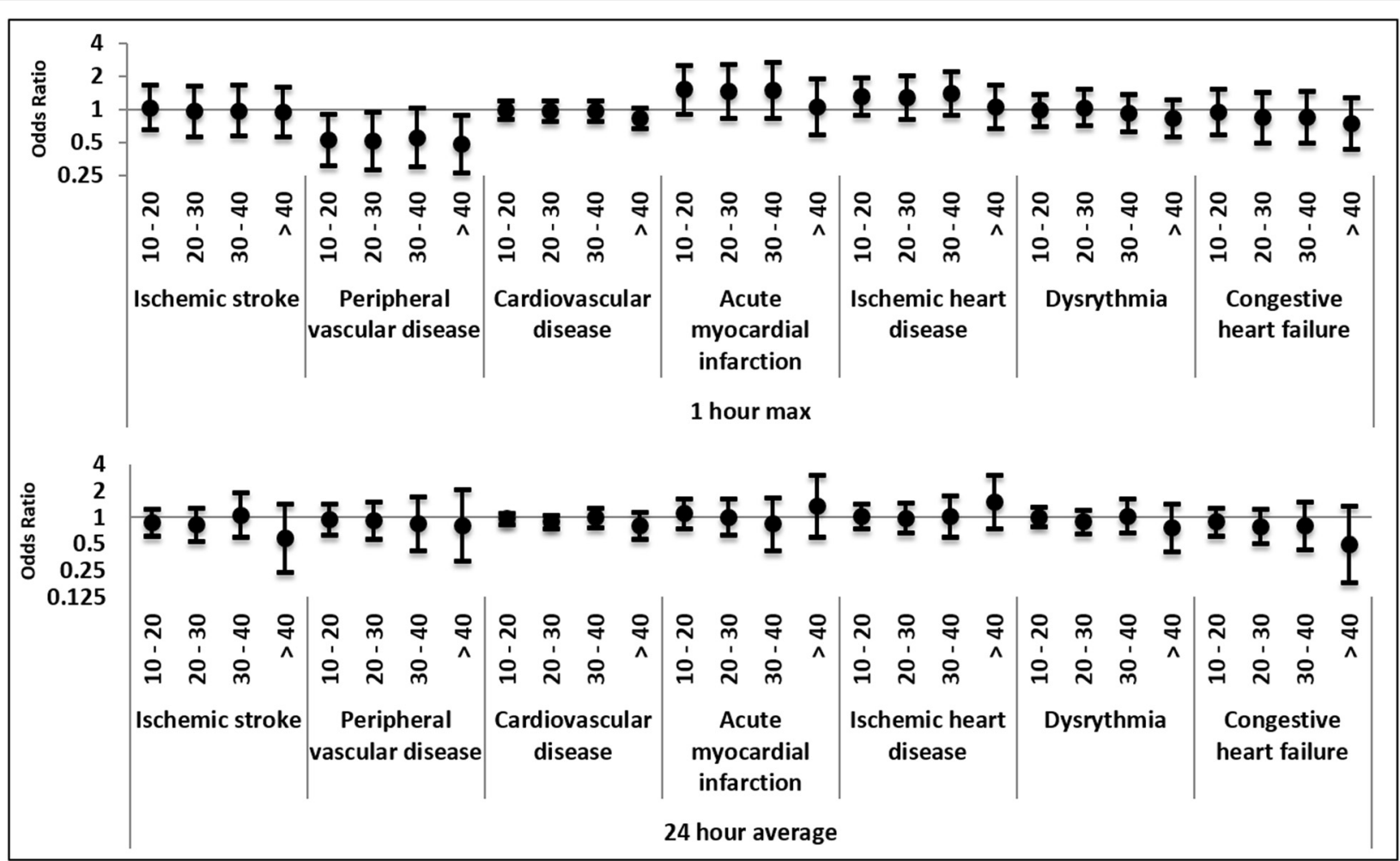

Referent group: $<10 \mu \mathrm{g} / \mathrm{m}^{3}$

Fig. 3 Concentration response odds ratios for cardiovascular outcomes for 24-h and 1-h maximum categorical PM 2.5

much higher than the first two categorical (up to $20 \mu \mathrm{g} / \mathrm{m}^{3}$ ) groups during a non-wildfire period, as only one $\mathrm{PM}_{2.5} 24 \mathrm{~h}$ maximum concentration was recorded above $35.5 \mu \mathrm{g} / \mathrm{m}^{3}$ in 2012 [28]. Thus, all categorical groups of exposure above the first two are likely to be primarily capturing $\mathrm{PM}_{2.5}$ from wildfires.

The short study period limited the number of ED visits available for analysis, which raises concerns about statistical power. Many confidence interval estimates were large, and given this lack of precision we may have been unable to identify modest increases in risk for several of the morbidities. Even so, we did observe positive associations with respiratory disease, asthma/wheeze, and COPD.

We were unable to account for seasonal variations in ED visits, which could have resulted in confounding if the seasonal pattern of ED visits coincided with increases in $\mathrm{PM}_{2.5}$ concentrations. However, it is unlikely that seasonal variations in ED visits would fully explain the relationships, as $\mathrm{PM}_{2.5}$ concentrations had considerable spatial and temporal variation during the wildfire period, thus potentially obscuring any strong seasonal relationship that might normally exist.

During the Waldo Canyon fire, it was estimated that approximately 32,000 people evacuated the area [3]. It is possible that those who chose to evacuate had medical conditions that would make them more susceptible to $\mathrm{PM}_{2.5}$. Many of those who evacuated likely ended up in a different part of Colorado, and if they went to the hospital in a different area, their exposure classification would still be based on their Waldo Canyon area residence, resulting in an exposure misclassification. $91.1 \%$ of emergency department visits and hospitalizations could be geocoded, although it is unlikely that geocoding success was related to $\mathrm{PM}_{2.5}$ from wildfires. Similarly, this study was not able to take into account any longerterm effects or adaptations that may have occurred due to the Lower North Fork Fire and Little Sand Fire, which both occurred before June $5^{\text {th }}[29,30]$. In an analysis of health effects of the 2003 southern California fires, Kunzli, et al. [31], found that children with asthma were more likely to take preventative measures to reduce exposure and mitigate effects. In addition, when mitigation strategies are used, they have been effective at reducing indoor concentrations [32]. If adaptation due to longer exposures or previous exposures occurred we might expect results that were closer to the null. It is also possible that those exposed to wildfire smoke for long periods of time eventually stop trying to limit their exposure.

We are not able to quantify how the bias toward higher concentrations in the WRF-Chem model could 
have impacted our estimates, as we are not able to ascertain if exposure bias increased at the same time as daily case count were high. Furthermore, in some cases the model can be shifted in time and/or spatial location, leading to a larger percent different between observed and modelled data. As shown in Fig. 1, areas where the plumes were expected to be has considerably higher PM concentration than areas without the plume, and if the model was slightly off in the location of the plume it may show a large difference in PM concentration compared to the observed data.

\section{Conclusions}

In this study we estimated concentration-response effects of $\mathrm{PM}_{2.5}$ over a long-lasting fire period, and our analyses spanned a large geographic area. The study takes into account spatially varying exposure, rather than assigning a uniform exposure during wildfire periods, and also accounts for day to day temporal variability in $\mathrm{PM}_{2.5}$. The conditional logistic regression models were able to control for the spatial variations in socioeconomic status and population density at the $12 \mathrm{~km}$ by $12 \mathrm{~km}$ grid level.

People are exposed to wildfire particulate matter relatively infrequently compared to other ambient air pollutants, but there is some evidence to suggest that $\mathrm{PM}_{2.5}$ from wildfires may have a stronger adverse effect on respiratory morbidity at the same levels [33], and that there is a difference in toxicological response based on particulate matter source [7, 8, 33]. With climate change, researchers project both longer burn periods and more intense fires, and thus the potential for a greater number of people experiencing adverse health effects due to exposure to wildfire smoke. Furthermore, these smoke plumes may move great distances, impacting people not located near the wildfire itself [34]. Future studies should focus on tracking evacuation and behavior patterns during wildfire periods to help elucidate uncertainties related to exposure measurement error that may be unique to this type of event. While this study, combined with previous toxicological and epidemiologic studies, provides evidence for adverse health effects with exposure to wildfire air pollutants, large gaps in knowledge still exist. This is particularly important when considering that lengthier burn seasons and more intense fire periods are projected for the future $[35,36]$.

\section{Additional files}

Additional file 1: Figure S1. A Monitor data compared to co-located modelled data. A figure showing the $24 \mathrm{~h}$ and hourly (When available) monitor data compared to the modelled data at the same time and location. (PDF $570 \mathrm{~kb}$ )
Additional file 2: Table S1. A The number of cases per categorical PM. A table of the number of cases for each respiratory and cardiovascular outcome by $24 \mathrm{~h}$ mean and $1 \mathrm{~h}$ max categorical PM. Each category represents a 10ug/m3 increase in PM2.5 concentration. (DOCX $17 \mathrm{~kb}$ )

\section{Abbreviations}

CHF, congestive heart failure; COPD, chronic obstructive pulmonary disease; $C V D$, cardiovascular disease; ED, emergency department; $I H D$, ischemic heart disease; MI, acute myocardial infarction; OR, odds ratio; PM, particulate matter; WRF- Chem, Weather Research and Forecasting Model with Chemistry

\section{Acknowledgements}

The authors would like to acknowledge Christine Wiedinmyer (NCAR) and Sean Raffuse (Sonoma Technology) for providing the fire emission inventory. We further acknowledge the Air Pollution Control Division of the Colorado Department of Health (CDPHE) for help with the surface monitoring data, Kirk Bol at CDPHE for providing the health data.

The views expressed in this paper are those of the authors and do not necessarily reflect the views or policies of the U.S. Environmental Protection Agency.

\section{Funding}

Funding from the U.S. National Aeronautics and Space Administration (NASA) grant NNX11AI53G and NASA AQAST project NNX11AI51G. The funding agency had no input on the design of the study, on the collection, analysis, and interpretation of data, or in the writing the manuscript. NCAR is operated by the University Corporation of Atmospheric Research under sponsorship of the National Science Foundation.

Availability of data and materials

Per data use agreements the health data are not permitted to be shared.

\section{Authors' contributions}

BLA, HH, JS, and MJS contributed to the epidemiologic analyses and $G B, X H$, and $Y L$ contributed to the exposure modeling and linking the exposure and health data. All authors have reviewed and made contributions to the manuscript. All authors read and approved the final manuscript.

\section{Competing interests}

The authors declare that they have no competing interests.

Consent for publication

Not applicable.

Ethics approval and consent to participate

No individual human data reported.

This study was approved by the Emory University Institutional Review Board, protocol 66505.

\section{Author details}

${ }^{1}$ The Office of Air Quality Planning and Standards, United States Environmental Protection Agency, 109 T.W Alexander Dr, Research Triangle Park, NC 27711, USA. ${ }^{2}$ National Center for Atmospheric Research, 3450 Mitchell Lane, Boulder, CO 80301, USA. ${ }^{3}$ Department of Environmental Health, Rollins School of Public Health, Emory University, 1518 Clifton Rd NE, Atlanta, GA 30322, USA. ${ }^{4}$ School of Community Health Sciences, University of Nevada, Reno, 1664 North Virginia Street, Reno, NV 89557, USA.

Received: 1 February 2016 Accepted: 20 May 2016

Published online: 04 June 2016

\section{References}

1. High Park Fire Grows Over Weekend Of High Winds, Record Heat; Dozens More Homes Destroyed. [http://www.huffingtonpost.com/2012/06/25/highpark-fire-grows-over_n_1623925.html?utm_hp_ref=denver]. Accessed 22 Sept 2013.

2. 2012 Colorado Wildfires- at glance. [http://www.denverpost.com/wildfires/ ci_20998199/2012-colorado-wildfire-overview]. Accessed 22 Sept 2013. 
3. Colorado wildfire: 32,000 people evacuated in Waldo Canyon fire. [http:// www.denverpost.com/ci_20940351/colorado-wildfire-waldo-canyon-firenear-colorado-springs]. Accessed 22 Sept 2013.

4. Hodzic A, Madronich S, Bohn B, Massie S, Menut L, Wiedinmyer C. Wildfire particulate matter in Europe during summer 2003: meso-scale modeling of smoke emissions, transport and radiative effects. Atmos Chem Phys. 2007;7: 4043-64.

5. U.S. Environmental Protection Agency. Integrated Science Assessment for Particulate Matter. Washington, DC: U.S. EPA; 2009.

6. Liu JC, Pereira G, Uhl SA, Bravo MA, Bell ML. A systematic review of the physical health impacts from non-occupational exposure to wildfire smoke. Environ Res. 2015;136:120-32.

7. Nakayama Wong LS, Aung HH, Lame MW, Wegesser TC, Wilson DW. Fine particulate matter from urban ambient and wildfire sources from California's San Joaquin Valley initiate differential inflammatory, oxidative stress, and xenobiotic responses in human bronchial epithelial cells. Toxicol In Vitro. 2011;25(8):1895-905.

8. Wegesser TC, Franzi LM, Mitloehner FM, Eiguren-Fernandez A, Last JA. Lung antioxidant and cytokine responses to coarse and fine particulate matter from the great California wildfires of 2008. Inhal Toxicol. 2010;22(7):561-70.

9. Delfino RJ, Brummel S, Wu J, Stern H, Ostro B, Lipsett M, Winer A, Street DH, Zhang L, Tjoa T, et al. The relationship of respiratory and cardiovascular hospital admissions to the southern California wildfires of 2003. Occup Environ Med. 2009;66(3):189-97.

10. Rappold, Cascio WE, Kilaru VJ, Stone SL, Neas LM, Devlin RB, Diaz-Sanchez D. Cardio-respiratory outcomes associated with exposure to wildfire smoke are modified by measures of community health. Environ Health. 2012;11(71):1-9.

11. Schranz Cl, Castillo EM, Vilke GM. The 2007 San Diego Wildfire impact on the Emergency Department of the University of California, San Diego Hospital System. Prehosp Disaster Med. 2010;25(5):472-6.

12. Thelen B, French NH, Koziol BW, Billmire M, Owen RC, Johnson J, Ginsberg M, Loboda T, Wu S. Modeling acute respiratory illness during the 2007 San Diego wildland fires using a coupled emissions-transport system and generalized additive modeling. Environ Health. 2013;12:94.

13. Moore D, Copes R, Fisk R, Joy R, Chan K, Brauer M. Population health effects of air quality changes due to forest fires in British Columbia in 2003: estimates from physician-visit billing data. Can J Public Health. 2006;97(2): 105-8.

14. Rappold, Stone SL, Cascio WE, Neas LM, Kilaru VJ, Carraway MS, Szykman JJ, Ising A, Cleve WE, Meredith JT, et al. Peat bog wildfire smoke exposure in rural North Carolina is associated with cardiopulmonary emergency department visits assessed through syndromic surveillance. Environ Health Perspect. 2011;119(10):1415-20.

15. Hanigan IC, Johnston FH, Morgan GG. Vegetation fire smoke, indigenous status and cardio-respiratory hospital admissions in Darwin, Australia, 19962005: a time-series study. Environ Health. 2008;7:42.

16. Henderson SB, Brauer M, Macnab YC, Kennedy SM. Three measures of forest fire smoke exposure and their associations with respiratory and cardiovascular health outcomes in a population-based cohort. Environ Health Perspect. 2011;119(9):1266-71.

17. Johnston FH, Bailie RS, Pilotto LS, Hanigan IC. Ambient biomass smoke and cardio-respiratory hospital admissions in Darwin, Australia. BMC Public Health. 2007;7:240.

18. Morgan G, Sheppeard V, Khalaj B, Ayyar A, Lincoln D, Jalaludin B, Beard J, Corbett S, Lumley T. Effects of bushfire smoke on daily mortality and hospital admissions in Sydney, Australia. Epidemiology. 2010;21(1):47-55.

19. Grell GA, Peckham SE, Schmitz R, McKeen SA, Frost G, Skamarock WC, Eder B. Fully coupled "online" chemistry within the WRF model. Atmos Environ. 2005;39:6957-75.

20. Emmons LK, Walters S, Hess PG, Lamarque J-F, Pfister GG, Fillmore D, Granier C, Guenther A, Kinnison D, Laepple T, et al. Description and evaluation of the Model for Ozone and Related chemical Tracers, version 4 (MOZART-4). Geosci Model Dev. 2010;3(1):43-67.

21. Wiedinmyer C, Akagi SK, Yokelson RJ, Emmons LK, Al-Saadi JA, Orlando JJ, Soja AJ. The Fire INventory from NCAR (FINN): a high resolution global model to estimate the emissions from open burning. Geosci Model Dev. 2011;4:625-41.

22. Mitchell KE, Lohmann D, Houser PR, Wood EF, Schaake JC, Robock A, Cosgrove BA, Sheffield J, Duan Q, Luo L, et al. The multi-institution North American Land Data Assimilation System (NLDAS): utilizing multiple GCIP products and partners in a continental distributed hydrological modeling system. J Geophys Res: Atmos. 2004;109(D7):1-32.

23. Lu Y, Zeger SL. On the equivalence of case-crossover and time series methods in environmental epidemiology. Biostatistics. 2007;8(2):337-44

24. Ralph M, Edward T, Cyndi L, Zac A. Final technical memorandum No. 5: Fire emissions: Wildfires, Prescribed Burns and Agricultural Burning Emissions. Environ. 2012;1-19.

25. Silverman RA, Ito K. Age-related association of fine particles and ozone with severe acute asthma in New York City. J Allergy Clin Immunol. 2010;125(2): 367-73. e365.

26. Medina S, Le Tertre A, Quenel P, Le Moullec Y, Lameloise P, Guzzo JC, Festy B, Ferry R, Dab W. Air pollution and doctors' house calls: results from the ERPURS system for monitoring the effects of air pollution on public health in Greater Paris, France, 1991-1995. Evaluation des Risques de la Pollution Urbaine pour la Sante. Environ Res. 1997;75(1):73-84

27. Kim SY, Peel JL, Hannigan MP, Dutton SJ, Sheppard L, Clark ML, Vedal S. The temporal lag structure of short-term associations of fine particulate matter chemical constituents and cardiovascular and respiratory hospitalizations. Environ Health Perspect. 2012;120(8):1094-9.

28. Air Pollution Control Division. Colorado Air Quality Data Report 2012. Denver: Colorado Department of Public Health and Environment (CDPHE); 2013. p. 25-8.

29. Little Sand Fire Update 7/1/12 [http://www.fs.usda.gov/detail/sanjuan/newsevents/?cid=STELPRDB5377668]. Accessed 5 Feb 2016.

30. State of Colorado. Lower North Fork prescribed fire: prescribed fire review. 2012.

31. Kunzli N, Avol E, Wu J, Gauderman WJ, Rappaport E, Millstein J, Bennion J, McConnell R, Gilliland FD, Berhane K, et al. Health effects of the 2003 Southern California wildfires on children. Am J Respir Crit Care Med. 2006; 174(11):1221-8

32. Henderson DE, Milford JB, Miller SL. Prescribed burns and wildfires in Colorado: impacts of mitigation measures on indoor air particulate matter. J Air Waste Manag Assoc. 2005;55(10):1516-26.

33. Williams KM, Franzi LM, Last JA. Cell-specific oxidative stress and cytotoxicity after wildfire coarse particulate matter instillation into mouse lung. Toxicol Appl Pharmacol. 2013;266(1):48-55.

34. USGCRP. The Impacts of Climate Change on Human Health in the United States: A Scientific Assessment. In: Crimmins A, Balbus J, Gamble JL, Beard CB, Bell JE, Dodgen D, Eisen RJ, Fann N, Hawkins MD, Herring SC, et al. editors. Washington DC: US Global Change Research Program; 2016. Chapter 4 \& Chapter 9.

35. Westerling AL, Hidalgo HG, Cayan DR, Swetnam TW. Warming and earlier spring increase western U.S. forest wildfire activity. Science. 2006;313(5789): 940-3.

36. Liu YQ, Stanturf J, Goodrick S. Trends in global wildfire potential in a changing climate. Forest Ecol Manag. 2010;259(4):685-97.

\section{Submit your next manuscript to BioMed Central and we will help you at every step:}

- We accept pre-submission inquiries

- Our selector tool helps you to find the most relevant journal

- We provide round the clock customer support

- Convenient online submission

- Thorough peer review

- Inclusion in PubMed and all major indexing services

- Maximum visibility for your research

Submit your manuscript at www.biomedcentral.com/submit 